American Journal of Applied Sciences 8 (6): 547-553, 2011

ISSN 1546-9239

(C) 2011 Science Publications

\title{
Socio-Demographic Factors Affecting Attitude towards Information and Communication Technology Usage
}

\author{
Musa Abu Hassan, Bahaman Abu Samah, \\ Hayrol Azril Mohamed Shaffril and Jeffrey Lawrence D'Silva \\ Laboratory of Rural Advancement and Agriculture Extension, \\ Institute for Social Science Studies, University Putra Malaysia, Malaysia
}

\begin{abstract}
Problem statement: Rural development through ICT has been the focus of the Malaysian government. ICT is an important tool nowadays and in order to be a developed community, the community especially those in the rural areas must use it wisely. Besides the numerous benefits offered by the ICT, it would be helpful to know whether the rural community especially their leaders which are the Village Development and Security Committee (JKKK) members use ICT or not. Approach: This is a quantitative study and the respondents were selected based on the simple random sampling. A total of 240 JKKK members from four states in Peninsular Malaysia were selected as the respondents. A questionnaire was used to gather the data needed. Results: Results obtained revealed that their attitude towards ICT usage was moderate. Further analyses using Independent t-test and ANOVA have indentified that the factor of position held and level of education have significant difference with attitude towards ICT usage. The Pearson Product Moment Correlation performed have confirmed that the factors of period of using a computer in a week, period of using internet in a week and income per month have a positive and significant relationship with attitude towards ICT usage. On the other hand, the factors of period of staying in the Village Vision Movement and age have a negative and significant relationship with attitude towards ICT usage. Conclusion/Recommendation: It is recommended that ICT seminars and courses can be conducted to expose and train the JKKK members to be more competent in using ICT. Increasing the number of ICT centers in the community would provide more opportunity for JKKK members to learn more about ICT. These recommendations should be targeted to JKKK members in the lower management level, lower education, lower income, elderly and members who do not use computer and internet.
\end{abstract}

Key words: Attitude towards ICT, ICT seminars, rural development and village administrators, Village Vision Movement (VVM), village development and security committee

\section{INTRODUCTION}

Rural community development has been the focus of the Malaysia government since Malaysia gained its independence. To develop the rural community is not the responsibility of the government alone and the rural community as the main beneficiary of the rural development programs should also play their role (Nguanthaisong et al., 2011; Yassin et al., 2010); Meshkini et al. (2010) and Tolunay (2009) To gain the rural community cooperation in conducting the rural development programs, the government has established the Village Development and Security Committee or Jawatankuasa Kemajuan dan Keselamatan Kampung (JKKK) in Malay and the Village Vision Movement (VVM). JKKK has been established for more than 50 years. Among others, the JKKK plays a leading role in creating a more advanced and developed rural community. In addition, JKKK has become one of the government channels to overcome problems such as poverty, health, illiteracy and lackadaisical attitude that exist within the rural community. Improvement and adjustment have been made to ensure the roles of JKKK to meet its purposes. Programs such as Moving Forward Program, Self-Success and Innovation Movement were introduced to ensure that these changes are successful. The VVM is another government medium to create consciousness and positive attitude among the rural community in achieving success of the Second Plan on Rural Transformation. Among the purposes of VVM are to create rural community who are resilient, have high initiative, self-dependent,

Corresponding Author: Musa Abu Hassan, Laboratory of Rural Advancement and Agriculture Extension,

Institute for Social Science Studies, University Putra Malaysia 
knowledgeable and highly disciplined which is in line with the demand of basic modernization. VVM is a catalyst needed by the government that will focus on the attractive and profitable rural development programs which is parrell to the Rural Development Policy.

It is without doubt that the development of rural areas is mostly related to agriculture projects (Hayrol Azril et al., 2010; Jeffrey Lawrence et al., 2010, Md. Salleh et al., 2010a; 2010b; Jegak et al., 2010; Rahman et al., 2011). Similarly, ICT also has an important role to prosper development in these areas (Bahaman et al., 2011; Rittidet et al., 2009). There are a number of ICT development plans and programs that have been initiated and one of the main targets of these plans and programs is the rural community. Among the programs and plans initiated were the National Information Technology Agenda (NITA), Universal Services Provider (USP) and One Home One Computer campaign. The recent ICT program introduced by the government is the National Broadband Initiatives (NBI). The main objective of NBI is to ensure that $50 \%$ of the Malaysian household posses broadband by the end of 2010. To achieve this, the government has launched five initiatives to support NBI which are Community Internet Centers (Pusat Internet Rakyat), Mini Community Broadband Centers, One Million Netbook Initiative, setting up of E-Kiosks CBC to the home and expansion of cellular coverage. Nevertheless, by having these great plans and programs, do the rural community as the main beneficiary of such programs and initiatives use ICT? And more importantly, do they have a positive attitude towards ICT usage? Positive attitude is deemed important to construct positive ICT usage among the rural community especially their leaders who are the JKKK members.

Attitude is seen as an evaluative disposition based upon cognitions, affective reactions, behavioral intention and past behaviors and it provides the response of someone's like or dislike towards something (Shih, 2004; Luarn and Lin, 2004). Previous studies have tried to seek the relationship that might occur between attitude and ICT usage among the rural community. Shiro (2008) for example, through his research, has proved that rural community possess positive attitude towards ICT and they welcome any ICT project to be built in their areas. However, Shiro (2008) also found that their lack of ICT knowledge reduces their ICT usage. Dixon (2009) has concluded that ICT usage and exposure are the important things needed to form a positive attitude towards ICT. Frequent use and exposure to ICT will drive people to accept that ICT will assist them and become useful in their daily life. Thus, this is an indication of creating a positive attitude towards ICT usage. Also, Dixon
(2009) noted that frequent use and exposure to ICT will develop the strength of ICT knowledge and skills. Zhang and Aikman (2009) have another view when they claimed that attitude can be a mediator on the role of attitude towards behavioral intention.

Another important factor that can construct positive attitude towards ICT usage is the sociodemographic factors. A study done by Yuandong et al. (2005) concluded that age and gender will influence the attitude of rural community towards ICT usage. Gender has always been an important factor to constitute positive attitude and gender differences proved to have a significant impact on some studies (Sayan et al., 2004). Olatokun (2007) has come to a specific result when he claimed that females do have a positive attitude towards ICT usage. Income is one of the important factors to constitute a positive attitude towards ICT usage and this is not surprising as it is in tandem with what have been completed by Akman and Rehan (2010) and Lenhart and Horrigan (2003). Computer usage is another significant factor that can be associated with positive attitude towards ICT usage. People who use computer more will have a positive attitude towards ICT usage (Markus and Soh, 2002). The same results also occurred for Internet usage, those who use Internet more will have a positive attitude towards ICT (Markus and Soh, 2002). Education without doubt has a direct influence on ICT usage. Studies done by Roe and Broos (2005) and Bonfadelli (2003) have claimed that low educated people possess negative attitude towards ICT usage while people with high level of education will have a positive attitude towards ICT usage. As such, it would be useful to know whether besides these findings, the situation also occurs in Malaysia especially among the JKKK members. Thus, the main objective of this study is to investigate the influence of socio-demographic factors on JKKK member's attitude towards ICT usage.

\section{MATERIALS AND METHODS}

This is a quantitative study using survey questionnaire. The result of pre test showed that the Cronbach alpha value was 0.971 , thus indicating that the instrument used in this study showed a good level in term of reliability and exceeding the recommended alpha value as mentioned by Nunnally (1967) and Mohd (1998). Based on the simple random sampling employed, a total of $240 \mathrm{JKKK}$ members were selected as respondents. The selected respondents were from four states of Kedah (Northern zone), Terengganu (East 
coast zone), Perak (Central zone) and Johor (Southern zone) of the Peninsular Malaysia. Each of the states was represented by 60 respondents. Face to face interview was conducted to collect the data. The data gathered was analyzed using SPSS where descriptive statistics such as frequency, percentage, mean, standard deviation, independent t-test, ANOVA and Pearson product-moment correlation were employed. The independent variables for this study were gender, age, level of education, type of job, income per month, period of holding a position in JKKK, position held in JKKK, period of staying in their village, period of computer usage in a week and period of Internet usage in a week. The dependent variable for this study was JKKK members' attitude towards ICT usage.

\section{RESULTS}

Table 1 shows the socio-demography profile of the respondents. A large majority of the respondents $(82.1 \%)$ were males. Comparatively, more than one third of the respondents (34.2\%) were in the age group of 41-50 years old, $25.0 \%$ of the respondents were in the age group of 5160 years old, $21.2 \%$ of the respondents were in the age group of less than_ 40 years and less than one fifth of the respondents $(19.6 \%)$ were in the age group of $\geq 61$ years. More than half of the respondents $(52.5 \%)$ possessed SPM/SPMV level of education while only slightly more than one fifth of the respondents (20.4\%) possessed university and pre university level of education. A total of $35.5 \%$ of the respondents were self-employed and a total of $37.1 \%$ of the respondents earned more than RM1, 501 a month. More than two fifth of the respondents have held the JKKK position for less than 5 years (42.1\%) compared to those who have held the JKKK position for more than 11 years $(22.5 \%)$. A total of $62.5 \%$ of the respondents have stayed in their village for more than 30 years. A total of $45.4 \%$ of the respondents have used the computer for a period of 1-9 hrs per week, while more than a quarter of them $(28.8 \%)$ have used the internet for more than 8 years.

To measure the dependent variable of this study which is the attitude of JKKK members towards ICT usage, a cumulative value from eight statements was developed. Then, the cumulative value was grouped into three levels namely low (1-3.33), moderate (3.346.67) and high (6.68-10.0). Based on the overall mean score for attitude towards ICT usage $(\mathrm{M}=5.91$, from a maximum of 10.0) it can be concluded that more than half of the respondents have a low to moderate level of attitude towards ICT usage and almost half have a high level of attitude towards ICT usage (Table 2).
A total of eight statements have been included in the instrument for the purpose of measuring attitude towards ICT usage. Based on the results shown in Table 3, it can be seen that the statement of "I encourage other JKKK members and my family members to use ICT" recorded the highest mean score of 6.77 .

Table 1: Socio-demography profile of the respondents

\begin{tabular}{lll}
\hline Variables & Frequency & Percentage Mean
\end{tabular}

Gender

Male

Female

Age

$<40$ years

41-50 years

51-60 years

$>61$ years

Level of education

PMR* and primary

school

SPM/SPMV**

University and

Pre University

Type of Job

Self-employed

Retiree/housewives

Government

Private

Income per month

$<$ RM750

RM751-RM1500

$>$ RM1501

Value in Ringgit

Malaysia (RM)

Period of holding a

position in VDSC

$<5$ years

6-10 years

$>11$ years

Position

Top management

Committee

Period of staying in

their village

$<30$ years

$31-45$ years

$>46$ years

Period of computer

usage a week

$0 \mathrm{~h}$

$1-9 \mathrm{~h}$

$>10 \mathrm{~h}$

Period of internet

usage a week

$0 \mathrm{~h}$

$1-3 \mathrm{~h}$

$4-7 \mathrm{~h}$

$>8 \mathrm{~h}$

$\begin{array}{rr}197 & 82.1 \\ 43 & 17.9\end{array}$

$51-21.2$

$\begin{array}{ll}51 & 21.2 \\ 82 & 34.2\end{array}$

$60 \quad 25.0$

$47 \quad 19.6$

$65 \quad 27.1$

$126 \quad 52.5$

$49 \quad 20.4$

$85 \quad 35.5$

$\begin{array}{ll}62 & 25.8 \\ 56 & 23.3\end{array}$

$\begin{array}{ll}56 & 23.3 \\ 37 & \end{array}$

$37 \quad 15.4$

$\begin{array}{ll}70 & 29.1\end{array}$

$81 \quad 33.8$

$89 \quad 37.1$

*: PMR-Malaysia lower education certificate; **: SPM/SPMVMalaysia higher education certificate/Malaysia vocational higher education certificate

Table 2: Overall level of attitude towards ICT usage

\begin{tabular}{lllll}
\hline Level & Frequency & Percentage & Mean & SD \\
\hline Low (1-3.33) & 45 & 18.8 & 5.91 & 2.48 \\
Moderate (3.34-6.67) & 85 & 35.4 & & \\
High (6.68-10.0) & 110 & 45.8 & & \\
\hline
\end{tabular}


Am. J. Applied Sci., 8 (6): 547-553, 2011

Table 3: Attitude towards ICT usage

\begin{tabular}{|c|c|c|c|c|c|c|c|c|c|c|c|c|}
\hline \multirow[b]{2}{*}{ Statement } & \multicolumn{10}{|c|}{ Scale } & \multirow[b]{2}{*}{ Mean } & \multirow[b]{2}{*}{ SD } \\
\hline & 1 & 2 & 3 & 4 & 5 & 6 & 7 & 8 & 9 & 10 & & \\
\hline $\begin{array}{l}\text { I encourage other JKKK } \\
\text { members and my family } \\
\text { members to use ICT }\end{array}$ & 5.0 & 7.1 & 2.1 & 5.4 & 9.2 & 8.3 & 14.2 & 20.8 & 10.8 & 17.1 & 6.77 & 2.64 \\
\hline $\begin{array}{l}\text { I emphasize on attending ICT courses } \\
\text { and seminars to enhance my } \\
\text { ICT knowledge and skills }\end{array}$ & 6.7 & 6.7 & 4.2 & 5.4 & 9.2 & 8.3 & 15.0 & 17.1 & 10.4 & 17.1 & 6.56 & 2.76 \\
\hline I feel left behind if I do not use ICT & 8.8 & 6.7 & 5.8 & 3.3 & 9.6 & 10.4 & 10.8 & 15.8 & 13.8 & 15.0 & 6.40 & 2.87 \\
\hline $\begin{array}{l}\text { I like to use the recent ICT tools } \\
\text { compared to the old one. }\end{array}$ & 12.9 & 11.2 & 4.2 & 6.7 & 10.0 & 7.5 & 13.8 & 13.8 & 12.1 & 7.9 & 5.64 & 2.95 \\
\hline $\begin{array}{l}\text { I feel excited in using ICT for my } \\
\text { daily tasks and village administrations }\end{array}$ & 12.5 & 10.4 & 5.0 & 6.2 & 8.8 & 12.9 & 13.8 & 15.0 & 7.1 & 8.3 & 5.58 & 2.85 \\
\hline $\begin{array}{l}\text { I feel comfortable to use ICT } \\
\text { because it is user friendly }\end{array}$ & 11.2 & 10.4 & 7.5 & 5.4 & 11.2 & 12.9 & 12.1 & 17.1 & 5.8 & 6.2 & 5.46 & 2.75 \\
\hline I prefer to use ICT compared to other tools & 12.1 & 11.2 & 5.8 & 10.2 & 11.2 & 6.7 & 12.9 & 13.3 & 6.7 & 10.0 & 5.45 & 2.91 \\
\hline $\begin{array}{l}\text { Using ICT gives me confident in my } \\
\text { daily tasks and village administrations }\end{array}$ & 12.1 & 10.8 & 5.4 & 8.8 & 10.4 & 11.2 & 11.7 & 15.0 & 8.8 & 5.8 & 5.43 & 2.80 \\
\hline
\end{tabular}

$1=$ highly disagree to $10=$ highly agree

Table 4: Comparison in attitude towards ICT usage for selected independent variables using independent t-test

\begin{tabular}{llllll}
\hline Variables & $\mathrm{n}$ & Mean & SD & $\mathrm{t}$ & $\mathrm{p}$ \\
\hline Gender & & & & 1.014 & 0.312 \\
Male & 197 & 5.99 & 2.46 & & \\
$\begin{array}{l}\text { Female } \\
\text { Position }\end{array}$ & 43 & 5.56 & 2.58 & & \\
$\begin{array}{l}\text { Top Management } \\
\text { Committee }\end{array}$ & 93 & 6.60 & 2.20 & 3.617 & 0.0001 \\
\hline
\end{tabular}

The second highest mean score was recorded by the statement of "I emphasize on attending ICT courses and seminars to enhance my ICT knowledge and skills" (6.56) while the statement of "I feel left behind if I do not use ICT" recorded the third highest mean score of 6.40. The statement of "Using ICT gives me confident in my daily tasks and village administrations" had the lowest mean score of 5.43 among the statements used.

The influence of socio-demographic factors on JKKK members' attitude towards ICT usage will be explored and discussed. For this purpose, inferential analysis using independent t-test was employed.

Based on the results presented (Table 4) it can be concluded that there was no significant difference between male and female in their attitude towards ICT usage. This is based on $\mathrm{M}=5.99, \mathrm{SD}=2.46$ for male respondents and $\mathrm{M}=5.56, \mathrm{SD}=2.58 ; \mathrm{t}(240)=1.014$, $\mathrm{p}=0.312$ for female respondents. This indicates that there is a possibility that male and female respondents have an equal level of attitude towards ICT usage.

For the factor of position held in JKKK, based on the independent $\mathrm{t}$-test done, it was found that there was significant difference in attitude towards ICT usage between JKKK committee members and JKKK top management members. This can be proved based on $\mathrm{M}=6.60, \mathrm{~S} . \mathrm{D}=2.20$ for top management members and $\mathrm{M}=5.48$, S.D $=2.56$; $\mathrm{t}(240)=3.167$, $\mathrm{p}=0.0001$ for committee members. There is a possibility that the top management members posses a better attitude towards ICT usage based on the higher mean score recorded $(M=6.60)$.

To further understand the attitude of respondents towards ICT usage, ANOVA was performed to find out any differences that might occur in the factors of level of education and types of job. Results presented in Table 5 confirmed that there was a significant difference in attitude towards ICT usage in the factor of level of education. This is based on the $\mathrm{F}$ value $(3,240)$ $=29.304, \mathrm{p}<0.05$, that proved that there was a significant difference in attitude towards ICT usage between the three levels studied. Further analysis through post hoc test has revealed that there was a significant difference that occurred between those who possessed pre-university and university level of education with those who possessed SPM/SPMV and primary school and PMR level of education. Besides, there was also significant difference detected between those who possessed SPM/SPMV level of education and those who possessed primary school and PMR level of education. There is a possibility that those who possessed pre-university and university level of education benefited more from ICT usage based on the highest mean score recorded on their attitude towards ICT usage $(\mathrm{M}=7.32)$.

For the factor of types of job, the highest mean score was recorded by the group of government sector $(\mathrm{M}=6.56)$ while the lowest mean score was recorded by the group of self-employed $(\mathrm{M}=5.55)$. Based on $\mathrm{F}$ value $(4,240)=2.310, p>0.05$, it indicates that there was no significant difference in attitude towards ICT usage between the four groups studied. It can be concluded that all of the groups studied somewhat have an equal level of attitude towards ICT usage. 
Am. J. Applied Sci., 8 (6): 547-553, 2011

Table 5: Comparison in attitude towards ICT usage for selected independent variables using ANOVA

\begin{tabular}{llllll}
\hline Variables & $\mathrm{n}$ & Mean & SD & $\mathrm{F}$ & $\mathrm{P}$ \\
\hline Level of Education & & & & 29.304 & 0.0001 \\
PMR and Primary school & 65 & 4.24 & 2.52 & & \\
SPM/SPMV & 126 & 6.23 & 2.31 & & \\
Pre university and university & 69 & 7.32 & 1.51 & & \\
Type of Job & & & & 2.310 & 0.077 \\
Government & 56 & 6.56 & 2.09 & & \\
Private & 37 & 6.19 & 2.69 & & \\
Retiree/housewife & 62 & 5.65 & 2.42 & & \\
Self-employed & 85 & 5.55 & 2.62 & & \\
\hline
\end{tabular}

Table 6: Relationship between attitude towards ICT usage and selected independent variables

\begin{tabular}{lll}
\hline Variables & $\mathrm{R}$ & $\mathrm{P}$ \\
\hline Period of using computer in a week & 0.348 & 0.0001 \\
Income per month & 0.326 & 0.0001 \\
Period of using internet in a week & 0.223 & 0.0001 \\
Period staying in VVM village & -0.185 & 0.0040 \\
Age & -0.208 & 0.0010 \\
Experience & 0.018 & 0.7860 \\
\hline
\end{tabular}

In order to investigate for any relationship that might occur between attitude towards ICT usage and selected independent variables, Pearson productmoment correlation was performed. The result of the analysis is presented in Table 6 .

Based on the result gained, it can be stated that there was significant and positive relationship between attitude towards ICT usage and three independent variables namely period of using computer in a week, income per month and period of using internet in a week. While two independent variables namely period of staying in their village and age indicates significant and negative relationship with attitude towards ICT usage. However, there was no significant relationship identified between attitude towards ICT usage and experience in holding a JKKK position.

Based on the Guilford rule of thumb, the magnitude of four of the independent variables which are period of using computer in a week $(\mathrm{r}=0.348)$, income per month $(\mathrm{r}=0.326)$, period of using internet in a week $(r=0.223)$ and age $(r=-0.208)$ showed a low relationship with attitude towards ICT usage. However, one independent variable which was period of staying in the village $(r=-1.185)$ indicated a negligible relationship with attitude towards ICT usage.

\section{DISCUSSION}

Results gained have proved that JKKK members in Malaysia have a moderate level of attitude towards ICT usage. This study further detected that there were significant difference and significant relationship that occurred in attitude towards ICT usage in a number of socio-demographic factors. In order to increase the level of attitude towards ICT usage to a higher level and reduce the gap that exists within these factors, it is suggested that a number of alternatives such as conducting more courses and seminars for JKKK members. Other than that, ICT subsidy can be given to JKKK members and ICT centers can be established in the villages administered by JKKK. The target groups of such programs and initiatives must be JKKK members who are from the lower management members, lower educated, lower income, senior members, senior villagers and those who do not use computer and internet. Conducting ICT courses, seminars and house to house training are indeed important to enhance the attitude towards ICT usage. Raymond (1988) and Carey et al. (2002), suggested that the number of courses, seminars and training skills attended have a huge impact on the attitude towards ICT usage. The related agencies also must have a greater commitment to evaluate the success of the courses and seminars as this will reveal whether the courses and seminar have fulfilled its objectives or otherwise (Lee et al., 2008). Providing ICT subsidy will enhance ICT possession among the JKKK members especially those who are in the lower income category. It is hoped that, this initiative will drive them towards a positive attitude towards ICT usage. Previously, the Malaysian government has allowed those who have savings in the KWSP to withdraw their savings for the purpose of buying computers. However, currently it has been cancelled due to several reasons. Hopefully, such subsidy can be given again especially to JKKK members with a tight monitoring from the government. Having ICT facilities such as ICT centers is also one of the important elements to construct positive attitude towards ICT usage and this is not surprising as Zainab et al. (2002) and Hudson (2001) have agreed with this by saying that among the factors that will contribute to the people's positive attitude towards ICT usage are a reliable and robust ICT infrastructure and a conducive info-structural environment. Previous experiences have proved that ICT centers have assisted in reducing the digital inequality by providing access to ICT and more importantly by providing necessary training to socio economically disadvantaged (Jinqiu et al., 2007).

\section{CONCLUSION}

Based on the results obtained it can be concluded that JKKK members in Malaysia have a moderate level of attitude towards ICT usage. Independent t-test and ANOVA performed have indicated that the sociodemographic factors such as gender and type of position held in JKKK do have a significant difference 
in attitude towards ICT usage. Further analysis using Pearson product-moment correlation has detected that the factors of period of using computer in a week, income per month and period of using internet in a week have a positive and significant relationship with attitude of using ICT. However, there was a negative and significant relationship with attitude towards ICT usage detected on the factors of age and period of staying in the Village Vision Movement.

\section{REFERENCES}

Meshkini, A., K. Habibi, H. Alizade and S.R. Asl, 2010. Monitoring the impact of urban physical development plans on old sites of cities. Am. J. Environ. $\quad$ Sci., 6: 57-65. DOI: 10.3844/ajessp.2010.57.65

Akman, I. and M. Rehan, 2010. The predictive impact of socio-demographic factors and behavioral factors on professionals e-commerce attitudes. Scientific Res. Essays, 5: 1890-1898. http://academicjournals.org/SRE/PDF/pdf2010/18J ul/Akman\%20and\%20Rehan.pdf

Bahaman, A.S., M.S. Hayrol Azril, A.H. Musa and D.S. Jeffrey Lawrence, 2011. Can Technology Acceptance Model be Applied on the Rural Setting: The Case of Village Development and Security Committee in Malaysia. J. Soc. Sci., 7: 113-119. DOI: $10.3844 /$ jssp.2011.113.119

Bonfadelli, H., 2003. Online Communication: Putting the Knowledge Gap Theory into Perspective. In: Communication Research and Media Science in Europe: Perspectives for Research and Academic Training in Europe's Changing Media Reality, Schorr, A., W. Campbell and M. Schenk (Eds.). Walter de Gruyter, Berlin, pp: 656. ISBN: 3110172151,9783110172157

Carey, J., I. Chisholm and L. Irwin, 2002. The impact of access on perception and attitudes towards computers: An international study. J. Educ. Media Int., $\quad 39$ : 223-235. 10.1080/09523980210166431

Dixon, K.C., 2009. Attitudes towards ICT based interaction: A bachelor of education studies. http://www.aare.edu.au/09pap/dix091331.pdf

Hayrol Azril, M.S., A.N. Ahmad Faiz, I. Khairuddin, U. Jegak and D.S. Jeffrey Lawrence, 2010. Agriculture project as an economic development tool to boost socio-economic level of the poor community: The case of agropolitan project in Malaysia. Afr. J. Bus. Manage., 4: 2354-2361. ISSN: 1993-8233
Hudson, H.E., 2001. Telecentre Evaluation: Issues and Strategies. In: Telecentres: Case Studies and Key Issues the Commonwealth of Learning, Vancouver, Latcham, C. and D. Walker (Eds.)., Canada, pp: 169-181.

http://telecentres.isoc.am/references/book1/chapter 2016.pdf

Jeffrey Lawrence, D.S., M.S. Hayrol Azril, U. Jegak and A.S. Bahaman, 2010. Acceptance and sustainability of contract farming among youth in Malaysia. Am. J. Applied Sci., 5: 350-356. DOI: 10.3844/ajabssp.2010.350.356

Jegak, U., D.S. Jeffrey Lawrence, M.S. Hayrol Azril and A.S. Bahaman, 2010. The attitude, belief, support and knowledge level of the youth and their acceptance towards contract farming. J. Soc. Sci., 6: 350-355. DOI: 10.3844/jssp.2010.350.355

Jinqiu, Z., H. Xiaoming and I. Banerjee, 2007. The sustainability of public internet access centers: Lesson learned from ICT projects in rural China. Proceeding of the Conference on Empowering Rural Communities through ICT Policy and Research, Dec. 15-17, Chennai, India, pp: 1-17. http://www.cprsouth.org/wpcontent/uploads/drupal/Zhao_Jinqui.pdf

Lee, H., K. Ko, S. Jang and R. Heeks, 2008. Analysing South Korea's ICT for development ais programme. J. Electronic Information System in Developing Countries, 32: 1-15. ISSN: 1681-4835

Lenhart, A. and J.B. Horrigan, 2003. Revisualizing the digital divide as a digital spectrum. J. IT and Society, Online, 1 (5).

Luarn, P. and H. Lin, 2004. Towards an understanding of the behavioral intention to use mobile banking. J. Comput. Hum. Behav., 30: 1-9. DOI: 10.1016/j.chb.2004.03.003

Markus, M.L. and C. Soh, 2002. Structural influence on global e-commerce activity. J. Global Inform. Manage., $\quad 10: \quad 5-12 . \quad$ DOI: 10.4018/jgim.2002010101

Md. Salleh, H., M.S.H. Azril, A.M.S. Shahkat, A.S. Bahaman and R.N. Sabila, 2010a. Producing television agriculture program: Issues and problems among, Malaysian Television Producer. Am. J. Agric. Biol. Sci., 6: 356-360. DOI: 10.3884/jssp.2010.356.360

Md. Salleh, H., M.S.H. Azril, A.M.S. Shahkat, A.S. Bahaman and R.N. Sabila, 2010b. Producing Television Agriculture Program: Issues and Problems among Malaysian Television Producers. J. Soc. Sci., 6: 356-360. DOI: 10.3844/jssp.2010.356-360 
Nguanthaisong, P., S. Photisane and S. Laokka, 2011. Development of cultural and management inheritance by community participation. J. Soc. Sci., 7: 161-167. DOI: 10.3844/jssp.2011.161-167

Nunnally, J.C., 1967. Psychometric Theory. 3rd Edn., Mc-Graw Hill, New York, ISBN: 0071070885, pp: 640 .

Olatokun, W.M., 2007. Availability, accessibility and use of ICTs by Nigerian women academics. Malaysian J. Library Inform. Sci., 12: 13-33. http://majlis.fsktm.um.edu.my/document.aspx?File Name $=564$.pdf

Rahman, S.M.A., A. Haque and S.M.A. Rahman, 2011. Impact of fish farming on household income; a case study from mymensingh district. J. Soc. Sci., 127-131. DOI: 10.3844 jssp.2011.127-131

Raymond, L., 1988. The impact of computer training on attitudes and user's behavior of small business manager. http://www.questia.com/googleScholar.qst?docId= 5000109711

Rittidet, S., S. Rittidet, P. Rittidet and W. Sata, 2009. Community learning center for building alternative learning among youth. J. Soc. Sci., 5: 329-331. DOI: $10.3844 /$ jssp.2009.329.331

Roe, K. and A. Broos, 2005. Marginality in the information society; the socio-demographic of computer disquietude. Communication: J. Eur. Commun., $\quad 30:$ 91-96. DOI: 10.1515/comm.2005.30.1.91

Sayan, S., S. Elci and H. Acvi, 2004. Factors and impact in information society: A prospective analysis in the candidate countries, Report on Turkey. http://fiste.jrc.ec.europa.eu/download/EUR21383\% 20TURKEY\%20FINALwithannex.pdf
Yassin, S.M., H.A.M. Shaffril, M.S. Hassan, M.S. Othman and A.A. Samah et al., 2010. Prospects of waterway development as a catalyst to improve regional and community socio-economy level. Am. J. Econ. Bus. Admin., 2: 240-246. DOI: 10.3844/ajebasp.2010.240.246

Shih, H.P., 2004. Extended technology acceptance model of internet utilization behavior. J. Inform. Manage., 41: 719-729. DOI: 10.1016/j.im.2003.08.009

Shiro, U., 2008. A case study of DIY ICT. J. Inform., 10: 46-60. DOI: 10.1108/14636690810887535

Tolunay, A., A. Akyol and Y. Ince, 2009. Effects of globalization on lowland and upland villages in Anatolia: Case study on serpil and akbelenli villages. J. Applied Sci., 9: 1215-1226. DOI: 10.3923/jas.2009.1215.1226

Yuandong, Y., W. Zhan and T. Lai, 2005. How individual differences influence technology users behavior? Toward an integrated framework. http://www.allbusiness.com/technology/computersoftware-customer-relation/1054798-1.html

Zainab, A.N., A. Abrizah and N.N. Edzan, 2002. An information and communication technology (ICT enabled knowledge based Malay society. Malaysian J. Library Inform. Sci., 7: 1-15. http://majlis.fsktm.um.edu.my/document.aspx?File Name $=179$. pdf

Zhang, P. and S. Aikman, 2009. Attitudes in ICT acceptance and use. J. Comp. Sci., 1021-1030. DOI: 10.1007/978-3-540-73105-4_112 